\title{
Anthracnose Disease on Annual Bluegrass as Affected by Foot Traffic and Sand Topdressing
}

Joseph A. Roberts, Department of Plant Pathology, North Carolina State University, Raleigh, NC 27695; and James A. Murphy, Department of Plant Biology and Pathology, Rutgers, the State University of New Jersey, New Brunswick 08901

\begin{abstract}
Roberts, J. A., and Murphy, J. A. 2014. Anthracnose disease on annual bluegrass as affected by foot traffic and sand topdressing. Plant Dis. 98:1321-1325.

Sand topdressing is applied to maintain or enhance playability of the turf surface of putting greens. Anthracnose is a devastating disease of annual bluegrass (ABG; Pоа аппиа) putting green turf, caused by Colletotrichum cereale. The disease is more severe on weakened turf and reputed to be exacerbated by management practices that wound turf. A 2-year field study was initiated in 2007 to evaluate the effects of foot traffic ( 0 versus 327 footsteps $\mathrm{m}^{-2}$, equivalent to 200 rounds day ${ }^{-1}$ ) and sand topdressing ( 0 and 0.3 liter $\mathrm{m}^{-2}$ every week) on anthracnose severity of ABG mowed at $3.2 \mathrm{~mm}$. Surprisingly, foot traffic reduced

anthracnose severity as much as $28 \%$, regardless of sand topdressing, during both years. Although sand topdressing initially increased disease severity (up to $7 \%$ ) in 2007 , continued applications decreased severity by $9 \%$ later in August 2007 and again in 2008. The treatment combination of foot traffic 5 days week ${ }^{-1}$ and weekly sand topdressing resulted in the best turf quality by the end of both seasons. Results indicate that the practice of sand topdressing can be continued even under conditions of intense foot traffic and anthracnose disease development on $\mathrm{ABG}$ putting greens.
\end{abstract}

Anthracnose, caused by Colletotrichum cereale Manns sensu lato Crouch, Clarke, \& Hillman (4), is a destructive disease of putting green turf that occurs in two phases: a foliar blight, often problematic during the high temperatures and humidity of summer, and a basal rot, which can be observed throughout the year. Foliar blight is normally observed as chlorosis of the foliage that can lead to a loss of shoot density if untreated. Basal rot develops from colonization of the crown tissue that also produces irregular patches of chlorosis and eventual thinning. Black acervuli and setae occur with both phases and can often be observed with the naked eye; however, basal rot also produces blackening and rotting of the lower stem (28). Anthracnose can cause severe thinning of putting green turf, which greatly reduces aesthetics and playability. The disease is normally observed on annual bluegrass (ABG; Poa annua L. f. reptans (Hausskn) T. Koyama) but bentgrass species (Agrostis spp.) can also become infected. The frequency and severity of anthracnose on ABG putting greens has increased over the past two decades $(6,11,15,18,36)$. Management practices commonly employed on golf courses to improve playing conditions, such as low mowing height, low fertility, and limited irrigation, have been shown to increase abiotic stress and predispose the turf to anthracnose $(12,22)$. Plant health is known to affect plant disease severity; thus, it is important to understand how common management practices on putting greens influence the development of anthracnose.

Topdressing, as described by Beard (2), is the application of a thin layer of selected or prepared soil or sand to a turfgrass area. It is employed for smoothing or leveling of the playing surface, modification of the surface soil, covering stolons or sprigs of vegetative plants, and winter protection, and has been described as the most effective cultural practice to reduce and dilute thatch (intermixed organic layer consisting of living and nonliving shoots, stems, and roots) on putting greens $(2,16)$. Previous research has indicated that frequent sand topdressing (e.g., 0.3 liter $\mathrm{m}^{-2}$ every 7

Corresponding author: J. Roberts, E-mail: jarober3@ncsu.edu

Accepted for publication 2 April 2014.

http://dx.doi.org/10.1094/PDIS-08-13-0877-RE

(C) 2014 The American Phytopathological Society days) during the growing season can reduce anthracnose severity of ABG (13).

The wounding and bruising resulting from frequent foot traffic has been associated with enhanced plant disease because it may provide an entry point for fungi to colonize plant tissue $(1,2,25)$. Previous work has shown that wounding is not necessary to initiate anthracnose on corn (Zea mays L.), caused by C. graminicola (Ces.) C.G. Wilson; however, wounding prior to inoculation resulted in $100 \%$ of plants being infected within $48 \mathrm{~h}$ whereas only $76 \%$ of unwounded inoculated plants became infected in as long as 9 days (34). Additionally, Landschoot and Hoyland (15) observed faster anthracnose basal rot infection when puncture wounds were made at the crown but no symptoms when wounding occurred above the crown.

Although sand topdressing can reduce anthracnose severity in nontrafficked research trials (13), superintendents have questioned whether the positive effect of sand topdressing might be negated by frequent foot traffic. Moreover, many have questioned the relationship of frequent foot traffic to disease development due to the potential for compaction and wear damage. Sand topdressing has reduced wear damage on perennial ryegrass maintained as a football field (30) but the effects of topdressing on wear potential of putting green turf have not been previously examined. Therefore, the objectives of this study were to (i) evaluate the effect of foot traffic on the severity of anthracnose, turf quality, and compaction on ABG putting green turf and (ii) determine whether the suppression effect of frequent topdressing on anthracnose severity is independent of foot traffic.

\section{Materials and Methods}

Site description and maintenance. The study was conducted on an ABG turf stand grown on a Nixon sandy loam (fine, mixed, mesic typic Hapludult) with a $\mathrm{pH}$ of 6.3 at the Rutgers Horticultural Farm II in North Brunswick, NJ. The ABG turf was established in 2001, as described by Inguagiato et al. (11), using seed indigenous to the site as well as seed introduced from soil cores collected from golf course putting greens in Piscataway, NJ. Turf was mown 7 times week ${ }^{-1}$ using a walk-behind greens mower (models 220A and 220B; Deere \& Co.) with a bench height setting of $3.2 \mathrm{~mm}$. Irrigation was applied to avoid drought stress and maintain moderately dry soil conditions. Nitrogen was applied as a foliar spray using water-soluble sources at nitrogen rates of either 
4.9 or $9.8 \mathrm{~kg} \mathrm{ha}^{-1}$ totaling 195.3 and $143.0 \mathrm{~kg} \mathrm{ha}^{-1}$ in 2007 and 2008, respectively. Phosphorus and potassium were applied based on soil test results at 16.1 and $30.4 \mathrm{~kg} \mathrm{ha}^{-1}$ in 2007 and 0 and 56.3 $\mathrm{kg} \mathrm{ha}^{-1}$ in 2008, respectively. Trinexapac-ethyl (Primo Maxx; Syngenta Crop Protection) was applied at $0.048 \mathrm{~kg}$ a.i. ha ${ }^{-1}$ every 14 days from 12 May to 9 September 2007 and 7 May to 13 October 2008. Boscalid (Emerald; BASF), vinclozolin (Curalan EG; BASF), and flutalonil (ProStar WP; Syngenta Crop Protection) were applied each year to control dollar spot (caused by Sclerotinia homoeocarpa F.T. Benn.) and brown patch (caused by Rhizoctonia solani Kühn) (32). Algae was suppressed with mancozeb (Pentathlon LF; SePRO Corp.) applied at $21.4 \mathrm{~kg}$ a.i. $\mathrm{ha}^{-1}$ on 31 May, 20 June, and 7, 22, and 28 July 2007. Mancozeb was not required to suppress algae in 2008 .

The anthracnose epiphytotic was arrested after treatments were suspended each year to allow recovery of plots during the subsequent fall, winter, and spring months. Chlorothalonil was applied at $16.1 \mathrm{~kg}$ a.i. $\mathrm{ha}^{-1}$ on 10 September 2007 and at 9.2 and $11.2 \mathrm{~kg}$ a.i. ha $^{-1}$ on 16 September and 13 October 2008, respectively. Bentgrass encroachment was minimized with fluazifop-P-butyl (Fusilade; Syngenta Crop Protection) applied at $0.21 \mathrm{~kg}$ a.i. ha ${ }^{-1}$ on 23 August and 5 September 2007 and 18 September 2008. Broadleaf pests were controlled with mecoprop (MCPP; Nurfarm Americas Inc.) at $1.1 \mathrm{~kg}$ a.i. $\mathrm{ha}^{-1}$ on 23 August and 5 September 2007 and 18 September 2008 .

The experimental site was previously inoculated in July 2002 with $C$. cereale isolate ValP-04, as described by Inguagiato et al. (11). Disease outbreaks occurred naturally in subsequent years and C. cereale was reisolated from symptomatic leaf and stem tissue each year to confirm the presence of the pathogen.

Treatment design. This 2-year field study used a split-plot randomized complete block design with a two-by-two factorial arrangement of treatments replicated four times. The main plot factor consisted of foot traffic (using Adidas Z-Traxion golf shoes [Adidas USA] equipped with Black Widow Softspikes [Softspikes, LLC]), which was performed from eight starting positions at each end of a 0.25 - by 3.7-m-long traffic lane using methodology described by Roberts et al. (23). Starting positions were determined based on a $0.8-\mathrm{m}$ average stride length and $0.3-\mathrm{m}$ average sole length of three separate walkers (approximately $65 \mathrm{~kg}$ average) so that footsteps were applied evenly over each traffic lane. Walkers were blocked in the application of foot traffic so that any variation due to mass would be captured within the replication. The starting point for each traffic pass consisted of positioning the toe-end of both the left and right golf shoe at $0,0.2,0.4$, and $0.6 \mathrm{~m}$ from the end of each traffic lane, resulting in 16 total passes. Each main plot had four side-by-side traffic lanes creating a 1.0 - by $3.7-\mathrm{m}$ main plot. In total, 64 total passes (16 passes lane $\mathrm{e}^{-1}$ over four lanes; 327 footsteps $\mathrm{m}^{-2}$ ) per day were applied to main plots 5 days week ${ }^{-1}$. Data from Hathaway and Nikolai (9) indicate that as many as 323 footsteps $\mathrm{m}^{-2}$ occur in the area around the hole on a putting green that received 200 rounds of golf $\mathrm{day}^{-1}$. Foot traffic was applied between 1000 and $1300 \mathrm{~h}$ from 14 June to 4 September 2007 and 6 June to 7 September 2008. Subplots measuring 1.0 by $1.9 \mathrm{~m}$ were randomized within each main plot and were composed of topdressing plots with subangular silica sand $(\mathrm{pH} 5.8)$ at 0 or 0.3 liter $\mathrm{m}^{-2}$ every week from 14 May through 28 August 2007 and 15 May through 29 August 2008. Topdressing sand conformed to the particle size distribution recommended for sand putting green root zones (31) and was applied using a drop spreader (The Scotts Company). Sand was incorporated using a brush (91 by $23 \mathrm{~cm}$ ) constructed of three broom heads having medium-stiff synthetic bristles (model 7436; Harper Brush Works, Inc.) mounted to a plywood base with two extended handles. Sand was incorporated into individual plots by dragging the brush over half of the plot four times and repeating the procedure on the opposite half. The final treatment structure consisted of four total treatments: foot traffic + sand topdressing, foot traffic + no sand topdressing, nontraffic + sand topdressing, and nontraffic + no sand topdressing to serve as a negative control for both factors.
This study was performed in the same plot area over two growing seasons in an effort to examine long-term effects of foot traffic and sand topdressing on anthracnose development. Previous work by Inguagiato et al. (13) found that sequential applications of sand topdressing are needed to reduce anthracnose; however, the benefit of regular sand topdressing reducing anthracnose was observed earlier in the second year under an ongoing sand topdressing program. Additionally, multiple years of regular foot traffic provide opportunity for greater differences in soil bulk density, which could influence plant health and anthracnose and is more representative of actual conditions on a golf course putting green.

Data collection and analysis. Anthracnose severity was rated every 7 to 14 days from June to early September each year as the percent turf area infested with $C$. cereale using a line intercept-grid count method previously described by Inguagiato et al. (11) that resulted in 273 observations over $1.4 \mathrm{~m}^{2}$ of each plot. Symptoms for both basal and foliar anthracnose were recorded, though basal rot was most common. The percent turf area infested with $C$. cereale was then calculated using the formula $(n / 273) \times 100$, where $n$ represents the number of intersections observed over symptomatic leaf tissue. Turf quality was rated visually from June through September each year using a scale of 1 to 9 , where 9 represented the best quality and 5 the minimum acceptable quality (12). Turf density, uniformity, and color were components of the turf quality rating; the density and uniformity components were strongly affected by disease severity. To assess potential compaction from daily foot traffic, in situ soil bulk density was measured on 2 September 2007 and on 21 May, 3 and 17 June, 2 July, and 5 September 2008. Similar to Inguagiato et al. (12), readings were taken at three locations plot $^{-1}$ using a Troxler gamma-ray and neutron gauge (Model 3411-B; Troxler Electronic Laboratories Inc.) operated in the backscatter mode.

Sequential disease and quality assessments were utilized to determine the area under the disease progress curve (AUDPC) and area under the quality progress curve (AUQPC), respectively, which is a quantitative assessment over time calculated by the trapezoidal method:

$$
A=\sum_{i=1}^{N_{i}-1}\left[\left(y_{i}+y_{i+1}\right) / 2\right] \times\left(t_{i+1}-t_{i}\right)
$$

where $A=$ AUDPC/AUQPC, $i=$ interval point for rating, $N=$ number of ratings, $y=$ rating value, and $t=$ time point of rating (17). All data were evaluated by analysis of variance to identify significant treatment effects using the MIXED procedure for a split-plot design in Statistical Analysis System software (v. 9.3; SAS Institute). Year and year-treatment interactions were tested in the analysis. Means and significant interactions were separated using Tukey's honest significant difference at the 0.05 probability level.

\section{Results}

Anthracnose severity. There was a significant interaction of foot traffic and year, and the data for 2007 and 2008 are presented separately. Disease was first observed on 6 June 2007 and progressed to a maximum of $58 \%$ on 14 August 2007, after which disease severity declined during a period of rain and lower temperatures (approximately $26^{\circ} \mathrm{C}$ ) (Fig. 1). Disease severity increased again on 4 September as temperatures increased (approximately $34^{\circ} \mathrm{C}$ ) late in the summer. In 2008 , disease severity was first observed on 15 June. The disease progressed slowly due to rain and low temperatures in early June but increased steadily in mid-July, reaching a maximum disease severity (57\%) on 13 August (Fig. 2). Similar to 2007, rain and lower temperatures (approximately $26^{\circ} \mathrm{C}$ ) reduced disease severity on 20 August. Increased temperatures (approximately $34^{\circ} \mathrm{C}$ ) intensified disease severity (51\%) again by 7 September 2008.

Foot traffic significantly reduced disease in 2007 (Fig. 1) and 2008 (Fig. 2) when comparing individual rating dates and AUDPC (Table 1). The reduction in anthracnose by foot traffic was observed regardless of sand topdressing factor. The AUDPC in sandtopdressed plots was similar to no sand topdressing in 2007 (Table 1). Examination of individual rating dates showed that sand top- 
dressing increased anthracnose in June and July compared with nontopdressed plots but, as the disease progressed, nontopdressed plots had greater disease than topdressed plots by August (Fig. 1). Sand topdressing was significantly lower than nontopdressing in 2008, regardless of foot traffic factor, and the combination of foot traffic and sand topdressing had the least overall disease (Table 1; Fig. 2).

Turf quality. Quality of turfgrass with foot traffic was significantly higher than turfgrass with no traffic regardless of sand topdressing factor in 2007 (Table 1; Fig. 3). In 2008, foot traffic produced significantly higher turf quality when compared with no traffic (Table 1); however, an interaction showed that improved turf quality from foot traffic was only apparent in plots that received sand topdressing (Table 1). Sand topdressing had no effect on AUQPC in 2007 (Table 1). Similar to anthracnose development, topdressing initially had a negative effect on turf quality but continued applications improved turf quality by the end of the season (Fig. 3). Sand topdressing produced significantly higher quality than nontopdressing in 2008; however, these effects were only apparent in plots that received regular foot traffic (Table 1; Fig. 4). The combination of foot traffic and sand topdressing resulted in the best overall quality in both years of study.

Soil bulk density. Foot traffic increased the bulk density of the soil 1.3 to $8.9 \%$ on 2 September 2007 and on all dates in 2008 (Table 2). Topdressing generally had no effect on soil bulk density throughout the study, except when it interacted with foot traffic on 21 May and 3 June 2008, and indicated that foot traffic imposed on

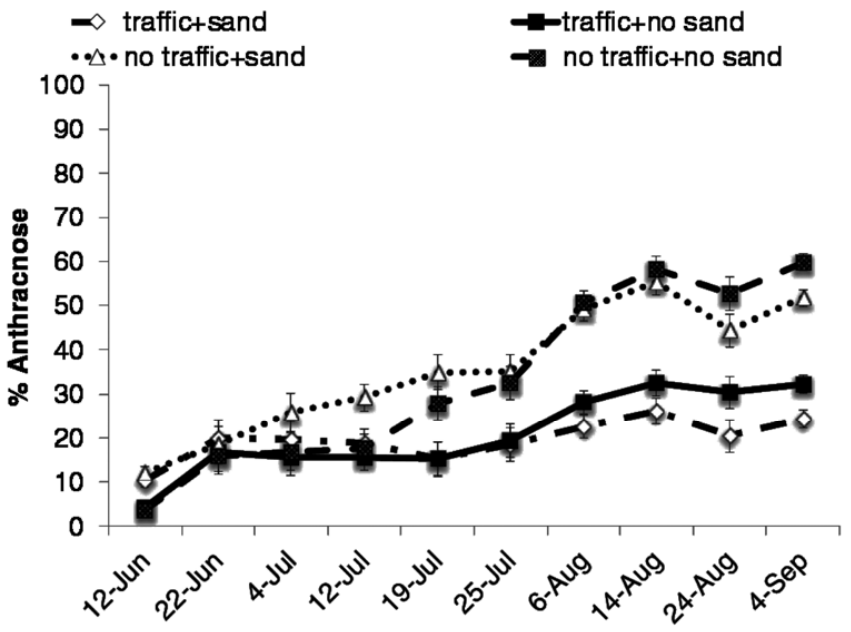

Fig. 1. Anthracnose response to foot traffic and topdressing on annual bluegrass turf mowed at $3.2 \mathrm{~mm}$ in North Brunswick, $\mathrm{NJ}$ during 2007. Anthracnose was rated using a line-intersect grid count method to determine percent turf area infested. Error bars represent Tukey's honest significant difference values at 0.05 probability. sand-topdressed turf increased soil bulk density sooner than foot traffic alone (data not shown).

\section{Discussion}

Although environmental and mechanical stresses are typically expected to increase disease severity (28), this study demonstrates that routine foot traffic stress does not enhance anthracnose severity. Inguagiato et al. $(11,14)$ indicated that light to moderate wounding caused by verticutting to a 3-mm depth at 14-day intervals during the summer and incorporating sand topdressing via vibratory rolling or stiff and soft brushes had no effect on disease severity. In our study, the stress imposed by foot traffic was routine and uniform over each plot and, therefore, it is possible that foot traffic reduced disease in a manner similar to lightweight rolling. Lightweight rolling has been shown to reduce anthracnose severity on ABG and dollar spot disease on creeping bentgrass $(7,12,24)$. Observations of reduced dollar spot from lightweight rolling were associated with higher volumetric water content, because drought stress can increase dollar spot severity (7). Like rolling, foot traffic could be beneficial by pressing plant tissue, mainly the crowns, and preventing meristematic tissue from elevating toward the surface; thus, reducing scalping from mowers (3) and improving contact between adventitious roots and the soil. This could result in improved plant health through increased nutrient and water uptake. It is also possible that regular foot traffic could disrupt the pathogen's hyphal extension across turf plants, thus inhibiting further foliar blight; however, this hypothesis has not been tested.

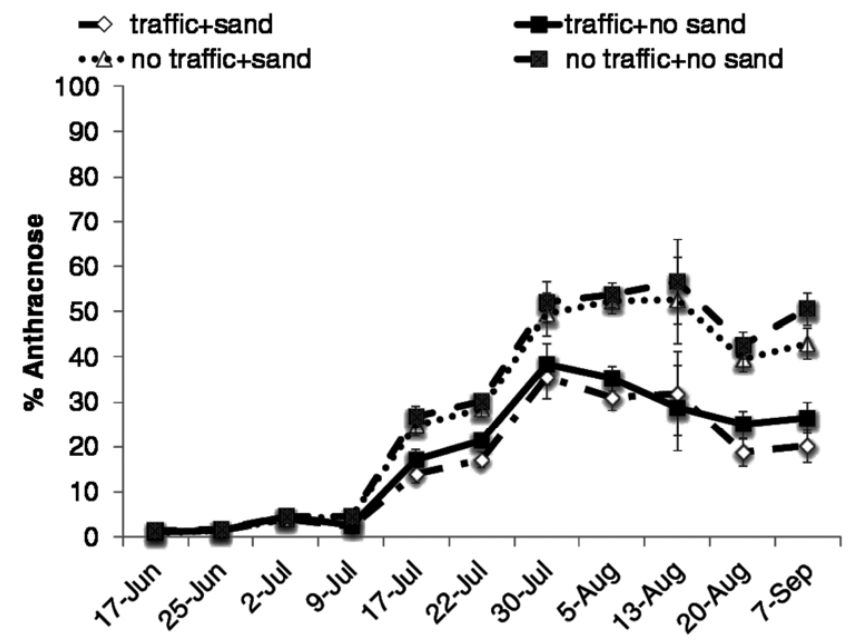

Fig. 2. Anthracnose response to foot traffic and topdressing on annual bluegrass turf mowed at $3.2 \mathrm{~mm}$ in North Brunswick, NJ during 2008. Anthracnose was rated using a line-intersect grid count method to determine percent turf area infested. Error bars represent Tukey's honest significant difference values at 0.05 probability.

Table 1. Area under disease and quality progress curve (AUDPC and AUQPC, respectively) response to foot traffic and topdressing on annual bluegrass turf mowed at $3.2 \mathrm{~mm}$ in North Brunswick, NJ during 2007 and 2008

\begin{tabular}{|c|c|c|c|c|}
\hline \multirow[b]{2}{*}{ Treatment $^{\mathrm{z}}$} & \multicolumn{2}{|c|}{ AUDPC $^{\mathbf{y}}$} & \multicolumn{2}{|c|}{ AUQPC } \\
\hline & 2007 & 2008 & 2007 & 2008 \\
\hline Foot traffic + sand & $1,637 \mathrm{~B}$ & $1,165 \mathrm{~B}$ & $361 \mathrm{~A}$ & $503 \mathrm{~A}$ \\
\hline Foot traffic + no sand & $1,762 \mathrm{~B}$ & $1,311 \mathrm{~B}$ & $344 \mathrm{AB}$ & $433 \mathrm{~B}$ \\
\hline No traffic + sand & $2,926 \mathrm{~A}$ & $1,956 \mathrm{~A}$ & 296 B & $458 \mathrm{~B}$ \\
\hline No traffic + no sand & $2,772 \mathrm{~A}$ & $2,093 \mathrm{~A}$ & $316 \mathrm{AB}$ & $438 \mathrm{~B}$ \\
\hline HSD & 358 & 153 & 44 & 23 \\
\hline \multicolumn{5}{|c|}{ Source of variation $(\operatorname{Pr}>F)$} \\
\hline Traffic & $<0.001$ & $<0.001$ & 0.004 & 0.02 \\
\hline Sand & NS & 0.003 & NS & $<0.001$ \\
\hline Traffic $\times$ sand & NS & NS & NS & 0.002 \\
\hline
\end{tabular}

y AUDPC and AUQPC representing season-long disease and turf quality values calculated using the trapezoidal method: $A=\sum_{i=1}^{N i-1}\left[\left(y_{i}+y_{i}+1\right) / 2\right] \times\left(t_{i}+1-\right.$ $t_{i}$ ) where $A=$ AUDPC/AUQPC, $i=$ interval point for rating, $N=$ number of ratings, $y=$ rating value, and $t=$ time point of rating. Letter designations represent significant differences using Tukey's honest significant difference (HSD) at the 0.05 probability level; NS $=$ not significant.

${ }^{\mathrm{z}}$ Foot traffic consisted of either none or 64 straight-line passes of foot traffic (approximately 327 footsteps $\mathrm{m}^{-2}$ ) per day from 14 June to 4 September 2007 and 6 June to 7 September 2008. Topdressing was applied biweekly as sand at 0.3 liter $\mathrm{m}^{-2}$ from 14 May to 28 August 2007 and 15 May to 29 August 2008 . 
Protection of the crown is essential because it is a key storage organ for the support and development of the plant (33). It was only through wounds on the crown (puncture and abrasion) that anthracnose basal rot was previously observed in the greenhouse (15), whereas wounding of plant leaf tissue resulted in no obvious symptom expression. If the crown is maintained lower in the mat layer or below the thatch, turf is less susceptible to temperature and drought stress (2). Hurto et al. (10) observed lower water retention in thatch of Kentucky bluegrass ( $P$. pratensis L.) when compared with an underlying silt loam, and Roberts et al. (22) previously observed increased anthracnose on water-stressed ABG putting green turf. Thus, stable temperatures and increased water retention have the potential to reduce plant stress, which can decrease the severity of stress-related diseases such as anthracnose (28).

Stress generated from regular foot traffic may have resulted in accumulation of reactive oxygen species (ROS), which are reduced derivatives of oxygen such as hydrogen peroxide $\left(\mathrm{H}_{2} \mathrm{O}_{2}\right)$ and nitric oxide that potentially damage carbohydrates, lipids, nucleic acids, and proteins (8). ROS production can be used by plants as signaling molecules for processes including systemic signaling and pathogen defense such as $\mathrm{H}_{2} \mathrm{O}_{2}$ and has been previously observed to induce cell-wall cross-linking and cellular protection and defense $(5,21)$. Further research should be completed to quantify ROS production in response to traffic stress.

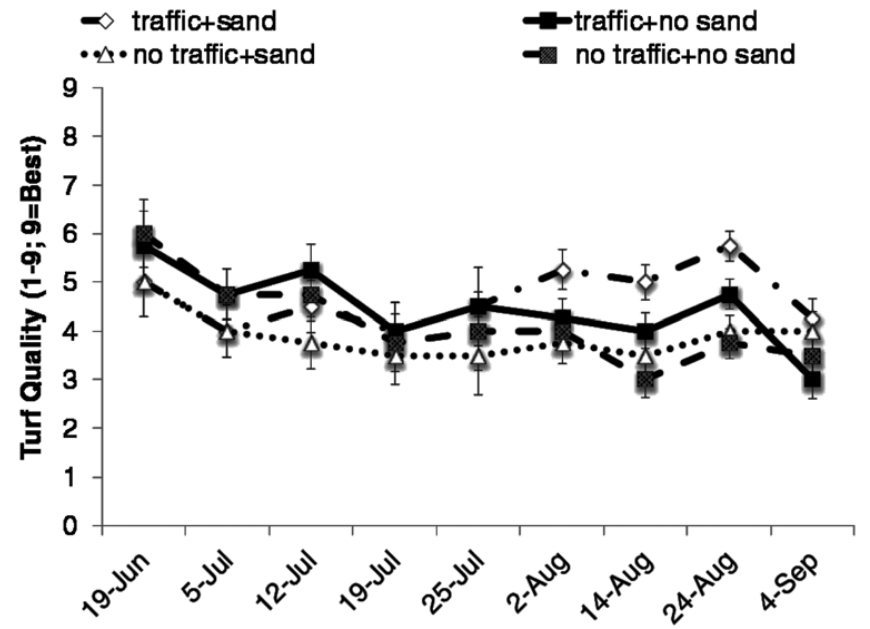

Fig. 3. Turf quality response to foot traffic and topdressing on annual bluegrass turf mowed at $3.2 \mathrm{~mm}$ in North Brunswick, NJ during 2007. Turf uniformity, density, and color were used to determine overall turf quality on a scale of 1 to 9 , with 9 being the best possible turf quality and 1 being completely dead. Error bars represent Tukey's honest significant difference values at 0.05 probability.
Sand topdressing increased anthracnose severity during June and July 2007; however, continued applications resulted in reduced anthracnose later in 2007 and again in 2008. Inguagiato et al. (13) observed similar results, with increases (i.e., $8 \%$ ) in anthracnose in the first year of topdressing and a subsequent reduction in severity thereafter. During initial sand topdressing applications, it is likely that the plant crowns are more exposed to wounding, which was reported by Landschoot and Hoyland (15) to increase anthracnose. However, continuous sand topdressing, as performed in our study, eventually buries plant crowns, resulting in a more upright growth habit of tillers and shoots by physically supporting the base of the plant, and allows plant crowns and roots to develop in a more soillike media instead of thatch (20). Topdressing has been shown to reduce mower scalp on creeping bentgrass (19) and bermudagrass (35) turf maintained as putting greens. The application of sand creates a firmer, more supportive playing surface that is less susceptible to mower scalp that better supports the weight of the mower and prevents it from sinking into the canopy and cutting off more leaf area. Reduced scalping is an indicator of an increased effective cutting height; slight increases in cutting height are known to reduce anthracnose severity (12).

The combination of foot traffic and sand topdressing resulted in the least anthracnose and best overall turf quality over the course of the study. In 2007, sand topdressing alone had the highest

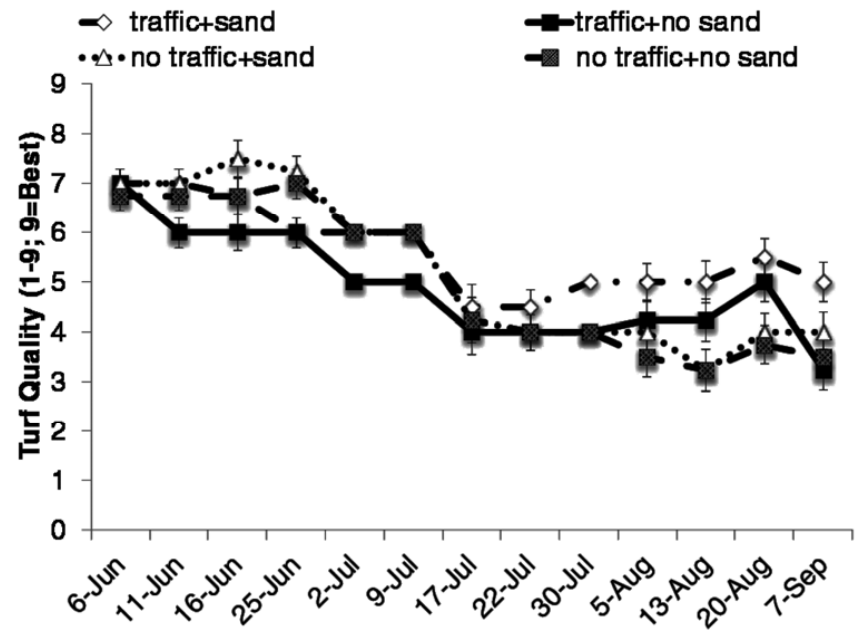

Fig. 4. Turf quality response to foot traffic and topdressing on annual bluegrass turf mowed at $3.2 \mathrm{~mm}$ in North Brunswick, NJ during 2008. Turf uniformity, density, and color were used to determine overall turf quality on a scale of 1 to 9 , with 9 being the best possible turf quality and 1 being completely dead. Error bars represent Tukey's honest significant difference values at 0.05 probability.

Table 2. Soil bulk density response to foot traffic and topdressing on annual bluegrass turf mowed at $3.2 \mathrm{~mm}$ in North Brunswick, NJ during 2007 and 2008

\begin{tabular}{|c|c|c|c|c|c|c|}
\hline \multirow[b]{3}{*}{ Main effects ${ }^{z}$} & \multicolumn{6}{|c|}{ Soil bulk density ${ }^{\mathrm{y}}\left(\mathrm{Mg} / \mathrm{m}^{3}\right)$} \\
\hline & \multirow{2}{*}{$\frac{2007}{2 \text { September }}$} & \multicolumn{5}{|c|}{2008} \\
\hline & & 21 May & 3 June & 17 June & 2 July & 5 September \\
\hline \multicolumn{7}{|l|}{ Foot traffic } \\
\hline 327 footsteps $\mathrm{m}^{-2}$ day $^{-1}$ & $1.34 \mathrm{~A}$ & $1.21 \mathrm{~A}$ & $1.30 \mathrm{~A}$ & $1.32 \mathrm{~A}$ & $1.41 \mathrm{~A}$ & $1.37 \mathrm{~A}$ \\
\hline None & $1.33 \mathrm{~B}$ & $1.19 \mathrm{~B}$ & $1.28 \mathrm{~B}$ & $1.27 \mathrm{~B}$ & $1.29 \mathrm{~B}$ & $1.30 \mathrm{~B}$ \\
\hline \multicolumn{7}{|l|}{ Topdressing } \\
\hline Biweekly & 1.37 & 1.21 & $1.29 \mathrm{~A}$ & 1.31 & 1.36 & 1.35 \\
\hline None & 1.36 & 1.20 & $1.28 \mathrm{~B}$ & 1.29 & 1.34 & 1.33 \\
\hline \multicolumn{7}{|c|}{ Source of variation (ANOVA) } \\
\hline Foot traffic & $<0.001$ & 0.012 & 0.003 & $<0.001$ & 0.006 & $<0.001$ \\
\hline Topdressing & NS & NS & 0.022 & NS & NS & NS \\
\hline Foot traffic $\times$ topdressing & NS & 0.005 & 0.004 & NS & NS & NS \\
\hline $\mathrm{CV}(\%)$ & 1.19 & 0.7 & 0.7 & 2.0 & 2.5 & 2.3 \\
\hline
\end{tabular}

y Soil bulk density measured using the Troxler Model 3411-B Neutron gauge operated in the backscatter mode. Letter designations represent significant differences using Tukey's honest significant difference (HSD) at the 0.05 probability leve. NS $=$ not significant.

${ }^{\mathrm{z}}$ Foot traffic consisted of either none or 64 straight-line passes of foot traffic 327 footsteps $\mathrm{m}^{-2}$ ) per day from 14 June to 4 September 2007 and 6 June to 7 September 2008. Topdressing was applied biweekly as sand at 0.3 liter $\mathrm{m}^{-2}$ from 14 May to 28 August 2007 and 15 May to 29 August 2008. ANOVA = analysis of variance and $\mathrm{CV}=$ coefficient of variation. 
AUDPC whereas the combination of traffic and sand topdressing had the lowest. Regardless, it is apparent that the addition of daily foot traffic to sand topdressed plots did not negate the beneficial effects of sand topdressing in reducing anthracnose severity. Moreover, these results confirm the concept that sand topdressing can and should be continued, even under heavy foot traffic, to reduce disease severity on $\mathrm{ABG}$ putting green turf.

Due to the level of both wear stress and disease damage, turf quality ratings were rarely above the minimum acceptable level $(\geq 5)$. These results illustrate that foot traffic was applied in a manner that mimics the decreased turf quality observed in putting greens. Additionally, plots receiving foot traffic and sand topdressing were either no different or better in turf quality compared with foot traffic alone showing that $\mathrm{ABG}$ turf tolerates frequent traffic better when topdressing is applied. Because foot traffic is a natural and continued occurrence on golf course putting greens, sand topdressing should be applied to reduce the negative effects of foot traffic observed in our study.

Foot traffic increased soil bulk density late in 2007 and 2008 regardless of sand topdressing. It is probable that foot traffic on sand-topdressed plots resulted in increased incorporation (packing) of sand, thus increasing the bulk density of the turf surface. Greater soil bulk density is normally associated with negative effects on plant growth $(26,29)$. However, the greater bulk density of trafficked plots in our study was associated with decreased anthracnose severity and improved turf quality, suggesting that the degree of compaction may not have been great enough to adversely affect plant growth. Compaction can inhibit ectomycorrhizal hyphae from extending within the soil (27); it may be possible that foot traffic inhibited hyphal extension of $C$. cereale, which would help explain the observed reduction in anthracnose in trafficked plots.

Regular foot traffic is a common occurrence on golf course putting greens. Although previous research generally highlights the negative aspects of foot traffic $(8,9,23)$, results from our study show that regular foot traffic can reduce anthracnose disease on ABG putting green turf. Additionally, the negative aspects of foot traffic such as decreased turf quality can be minimized through regular applications of sand topdressing. Thus, turf managers should consider routine sand topdressing as a component of best management practices for ABG putting green turf, even putting greens that receive heavy foot traffic. Although reductions in anthracnose disease with sand topdressing were not always large, regular application of sand topdressing in combination with proper management such as increased nitrogen fertilization, raising mowing heights, and maintaining adequate soil water content could potentially reduce the amount of fungicide required to adequately control anthracnose disease on ABG putting greens.

\section{Acknowledgments}

Support for this work was provided by the New Jersey Agricultural Experiment Station, State and Hatch Act Funds, and the Rutgers Center for Turfgrass Science. Additional support was provided by the United States Golf Association, Golf Course Superintendents Association of America, Golf Course Superintendents Association of New Jersey, and the Tri-State Research Foundation. We thank B. Ross, S. Cherniavski, and A. Pitonak for their aid in foot traffic; C. Arellano for her aid in statistical analysis; and Bruce Clarke and John Inguagiato for their aid in trial design.

\section{Literature Cited}

1. Agrios, G. N. 2005. Plant Pathology. Elsevier Inc., San Diego, CA.

2. Beard, J. B. 1973. Turfgrass Science and Culture. Prentice-Hall, Inc., Englewood Cliffs, NJ.

3. Beard, J. B. 2002. Turf Management for Golf Courses, 2nd ed. Ann Arbor Press, Chelsea, MI

4. Crouch, J. A., Clarke, B. B., and Hillman, B. I. 2006. Unraveling evolutionary relationships among the divergent lineages of Colletotrichum causing anthracnose disease in turfgrass and corn. Phytopathology. 96:46-60.

5. Delledonne, M., Xia, Y., Dixon, R. A., and Lamb, C. 1998. Nitric oxide functions as a signal in plant disease resistance. Nature 394:585-588.

6. Dernoeden, P. H. 2002. Creeping Bentgrass Management: Summer Stresses, Weeds, and Selected Maladies. John Wiley \& Sons, Inc., Hoboken, NJ.
7. Giordano, P. R., Nikolai, T. A., Hammerschmidt, R., and Vargas, J. M. 2012. Timing and frequency effects of lightweight rolling on dollar spot disease in creeping bentgrass putting greens. Crop Sci. 52:1371-1378.

8. Han, L. B., Song, G. L., and Zhang, X. 2008. Preliminary observations on physiological responses of three turfgrass species to traffic stress. HortTechnology 18:139-143.

9. Hathaway, A. D., and Nikolai, T. A. 2005. A putting green traffic methodology for research applications established by in situ modeling. Int. Turfgrass Soc. Res. J. 10:69-70.

10. Hurto, K.A., Turgeon, A. J., and Spomer, L. A. 1980. Physical characteristics of thatch as a turfgrass growing medium. Agron. J. 72:165-167.

11. Inguagiato, J. C., Murphy, J. A., and Clarke, B. B. 2008. Anthracnose severity on annual bluegrass influenced by nitrogen fertilization, growth regulators, and verticutting. Crop Sci. 48:1595-1607.

12. Inguagiato, J. C., Murphy, J. A., and Clarke, B. B. 2009. Anthracnose disease and annual bluegrass putting green performance affected by mowing practices and lightweight rolling. Crop Sci. 49:1454-1462.

13. Inguagiato, J. C., Murphy, J. A., and Clarke, B. B. 2012. Sand topdressing rate and interval effects on anthracnose severity of an annual bluegrass putting green. Crop Sci. 52:1406-1415.

14. Inguagiato, J. C., Murphy, J. A., Clarke, B. B., and Roberts, J. A. 2013. Topdressing sand particle shape and incorporation effects on anthracnose severity of an annual bluegrass putting green. Int. Turfgrass Res. Soc. J. 12:127-133.

15. Landschoot, P., and Hoyland, B. 1995. Shedding some light on anthracnose basal rot. Golf Course Manage. 11:52-55.

16. Ledeboer, F. B., and Skogley, C. R. 1967. Investigations into the nature of thatch and methods for its decomposition. Agron. J. 59:320-323.

17. Madden, L. V., Hughes, G., and van den Bosch, F. 2007. The Study of Plant Disease Epidemics. American Phytopathological Society, St. Paul, MN.

18. Mann, R. L., and Newell, A. J. 2005. A survey to determine the incidence and severity of pests and diseases on golf course putting greens in England, Ireland, Scotland, and Wales. Int. Turfgrass Soc. Res. J. 10:224-229.

19. McCarty, L. B., Gregg, M. F., and Toler, J. E. 2007. Thatch and mat management in an established creeping bentgrass golf green. Agron. J. 99:15301537.

20. Murphy, J., Wong, F., Tredway, L., Crouch, J., Inguagiato, J., Clarke, B., Hsiang, T., and Rossi, F. 2008. USGA Turfgrass Environ. Res. Online 7:116. http://usgatero.msu.edu/v07/n16.pdf

21. Orozco-Cardenas M. L., Narvaez-Vasquez, J., and Ryan, C. A. 2001. Hydrogen peroxide acts as a second messenger for the induction of defense genes in tomato plants in response to wounding, systemin, and methyl jasmonate. Plant Cell 13:179-191.

22. Roberts, J. A., Inguagiato, J. C., Clarke, B. B., and Murphy, J. A. 2011. Irrigation quantity effects on anthracnose of annual bluegrass. Crop Sci. 51:1244-1252.

23. Roberts, J. A., Inguagiato, J. C., and Murphy, J. A. 2013. A method to evenly apply foot traffic to turf plots. Int. Turfgrass Soc. Res. J. 12:743-746.

24. Roberts, J. A., Murphy, J. A., and Clarke, B. B. 2012. Lightweight rolling effects on anthracnose of annual bluegrass putting greens. Agron. J. 104:1176-1181.

25. Schumann, G. L., and D'Arcy, C. J. 2006. Essential Plant Pathology. American Phytopathological Society. St. Paul, MN.

26. Sills, M. J., and Carrow, R. N. 1983. Turfgrass growth, N use, and water use under soil compaction and N fertilization. Agron. J. 75:488-492.

27. Skinner, M. F, and Bowen, G. D. 1974. The penetration of soil by mycelia strands of ectomycorrhizal fungi. Soil Biol. Biochem. 6:57-61

28. Smiley, R. W., Dernoeden, P. H., and Clarke, B. B. 2005. Compendium of Turfgrass Diseases, 3rd ed. American Phytopathological Society, St. Paul, MN.

29. Sprague, N. B., and Burton, G. W. 1937. Annual bluegrass (Poa annua L.) and its requirements for growth. N. J. Agric. Exp. Stn. Bull. 630.

30. Spring, C. A., Wheater, J. A., and Baker, S. W. 2007. Fertiliser, sand topdressing, and aeration programs for football pitches. I. Performance characteristics under simulated wear. J. Turfgrass Sports Surface Sci. 83:40-54.

31. Staff, U. S. G. 2004. USGA recommendations for a method of putting green construction. U.S. Golf Assoc. Green Section Construction Educ. Progr. Waco, TX.

32. Towers, G., Green, K., Weibel, E., Majumdar, P., and Clarke, B. B. 2002. Evaluation of fungicides for the control of anthracnose basal rot on annua bluegrass, 2002. Fungic. Nematicide Tests 58:T017. www.plantmanagement network.org/pub/trial/fntests/reprints/2003/T017.pdf

33. Turgeon, A. J. 2005. Turfgrass Management, 5th ed. Reston Publishing Co., Inc., Reston, VA.

34. Venard, C., and Vaillancourt, L. 2007. Penetration and colonization of unwounded maize tissues by the maize anthracnose pathogen Colletotrichum graminicola and the related nonpathogen $C$. sublineolum. Mycologia 99:368-377.

35. White, R. H., and Dickens, R. 1984. Thatch accumulation in bermudagrass as influenced by cultural practices. Agron. J. 76:19-22.

36. Wong, F. P., and Midland, S. 2004. Fungicide-resistant anthracnose: Bad news for greens management. Golf Course Manage. 72:75-80. 